\title{
ANTENATAL SCREENING FOR HEPATITIS B AND C VIRUS CARRIER STATE AT A UNIVERSITY HOSPITAL
}

Sajida Yousfani, Firdous Mumtaz, Amna Memon, Muhammad Ali Memon and Raheel Sikandar

\begin{abstract}
OBJECTIVE: To determine hepatitis B virus (HBV) and hepatitis C virus (HCV) carrier state among pregnant women at gynaecology and obstetrics department of Liaquat University Hospital, Hyderabad -Sindh.

DESIGN: A descriptive study.

SETTING: Maternity units of Liaquat University Hospital, Hyderabad - Sindh from January 2003 to December 2003.

METHODS: One hundred and three pregnant women with $\mathbf{3 5}$ to $\mathbf{4 0}$ weeks of pregnancy admitted in maternity units due to obstetrical reasons were screened for hepatitis B and C seropositivity after they gave informed consent. Immuno- chromatography and ELISA technique were used for blood testing. Pregnant women with symptomatic liver disease were excluded from the study. Convenient sampling approach was adopted for the data collection.

RESULTS: Among screened population, 29.1\% of pregnant women were found positive for HBV or HCV. Out of these, $16.5 \%$ women were positive for HCV where as $12.6 \%$ for HBV. All women had history of injections and ear and nose prick where as $20 \%$ had positive history of blood transfusions, followed by history of jaundice among them or with their partner.

CONCLUSION: In our set up, frequency of $29.1 \%$ sero-positivity for HBV and HCV among pregnant women is alarming. These sero-positive mothers are not only at risk of having cirrhosis and liver cancer later on, but also are a continuous threat to their offsprings and care providers. Hence, there is a dire need to conduct more epidemiological studies on this problem and take measures for prevention and control of the disease.
\end{abstract}

KEY WORDS: Hepatitis B Virus. Hepatitis C Virus. Antenatal Care. Screening. Prevention.

\section{INTRODUCTION}

Infections due to hepatitis B and C viruses (HBV and $\mathrm{HCV}$ ) are significant health problems around the globe. Chronic hepatitis B virus infection affects over 350 million people worldwide and over one million die annually of HBV-related chronic liver disease. Although, many individuals eventually achieve a state of non-replicative infection, the prolonged immunologic response to infection leads to the development of cirrhosis, liver failure, or hepatocellular carcinoma in up to $40 \%$ of patients. In endemic areas, where carrier rates are $>5 \%$, most individuals are infected perinatally by vertical transmission, or in early childhood. ${ }^{1}$ Hepatitis C infection has an estimated sero-prevalance of 1-2\% in women of child bearing age and vertical transmission rate of $5-15 \%$. About $5 \%$ of infants born to women who are positive for both HCV antibody and HCV RNA during pregnancy acquire HCV infection. ${ }^{2}$ Prevalence of hepatitis $C$ in pregnancy has been studied in many countries of Europe ${ }^{3}$ and Africa. ${ }^{4}$ Considering WHO classification $^{5}$, Pakistan lies in intermediate zone with burden of hepatitis being $0.13 \%$ of total infectious diseases in the country. Being a vulnerable group, pregnant women are likely to be more infected, but there are very few studies on this subject. We conducted this study in our set up to find out the frequency of HCV and HBV in pregnant women. This work can also be basis for further studies to define the impact of HBV and HCV on the pregnancy.

\section{SUBJECTS AND METHODS}

This study was conducted at maternity units of Liaquat 
University Hospital (LUH), Hyderabad - Sindh from January 2003 to December 2003. LUH serves a large catchment area of Hyderabad district and interior of the Sindh. Women in maternity units are either admitted through out patients department or through casualty (emergency). After an informed consent, 3CC venous blood was drawn from 103 pregnant women admitted during study period and was sent to research and diagnostic laboratory for immunochromatographic test (ICT) or ELISA technique for detection of hepatitis B surface antigen (HBsAg) and anti-HCV antibodies. Majority (98.05\%) of the samples were tested by ICT because of the free availability of this test in our institution. ELISA method is relatively costly and only $2(1.94 \%)$ women were screened through it. Data of these women were recorded on a pre-designed proforma. Data collection also included risk factors of the disease including maternal age, parity, history of injection, ear and nose prick, blood transfusion, past history of jaundice, or jaundice in the partner. After data collection, it was analyzed through SPSS 10.0 version software program.

\section{RESULTS}

Among 103 pregnant women, 13(12.62\%) had HBsAg positive and 17 (16.5\%) had anti-HCV antibodies test positive (Table I). Majority of women (65\%) belonged to middle reproductive years. Younger women (13.6\%) showed increased frequency of HBV seropositivity (21.43\%) compared to HCV (14.28\%). Women in late reproductive years constituted $21.43 \%$ of the sample and showed a higher frequency of seropositivity for HCV i.e $22.73 \%$ and lowest for HBV i.e. $4.5 \%$. (Table II). Most of these pregnant women were having 1-4 children and they were found test positive in $23.4 \%$ and $19.15 \%$ of cases for HCV and HBV respectively (Table III). History of ear and nose pricks and injections were the commonest risk factors found in these women. Blood transfusions were also received by $20.39 \%$ of study subjects (Table IV).

\section{TABLE I:}

DISTRIBUTION OF HBSAG AND ANTI-HCV ANTIBODIES AMONG PREGNANT WOMEN $(n=103)$

\begin{tabular}{|l|c|}
\hline Number of women positive for HbsAg & $13(12.62 \%)$ \\
\hline $\begin{array}{l}\text { Number of women positive for Anti- } \\
\text { HCV antibodies }\end{array}$ & $17(16.5 \%)$ \\
\hline Negative for both viruses & $73(70.87 \%)$ \\
\hline
\end{tabular}

TABLE II:

SERO-POSITIVITY OF HBV AND HCV IN DIFFERENT AGE GROUPS $(n=103)$

\begin{tabular}{|l|c|c|c|}
\hline Age group & $\begin{array}{c}\text { Number } \\
\text { of } \\
\text { women }\end{array}$ & $\begin{array}{c}\text { Women } \\
\text { with } \\
\text { HBsAg } \\
\text { sero- } \\
\text { positivity }\end{array}$ & $\begin{array}{c}\text { Women } \\
\text { with sero- } \\
\text { positive } \\
\text { Anti-HCV } \\
\text { antibodies }\end{array}$ \\
\hline $\begin{array}{l}20 \text { years } \\
\text { and under }\end{array}$ & $14(13.6 \%)$ & $03(21.43 \%)$ & $02(14.28 \%)$ \\
$21-30$ years & $67(65.05 \%)$ & $09(13.43 \%)$ & $10(14.92 \%)$ \\
$31-40$ years & $22(21.36 \%)$ & $01(4.54 \%)$ & $05(22.73 \%)$ \\
\hline
\end{tabular}

TABLE III:

PARITY STATUS AND SERO-POSITIVITY OF HBV AND HCV $(n=103)$

\begin{tabular}{|l|c|c|c|}
\hline \multicolumn{1}{|c|}{$\begin{array}{c}\text { Parity } \\
\text { status }\end{array}$} & $\begin{array}{c}\text { Number } \\
\text { of } \\
\text { women }\end{array}$ & $\begin{array}{c}\text { Women } \\
\text { positive } \\
\text { for } \\
\text { HBsAg }\end{array}$ & $\begin{array}{c}\text { Women } \\
\text { positive for } \\
\text { anti-HCV } \\
\text { antibodies }\end{array}$ \\
\hline $\begin{array}{l}\text { Primigravi- } \\
\text { dae }\end{array}$ & $24(23.30 \%)$ & $01(4.17 \%)$ & $02(8.33 \%)$ \\
$\begin{array}{l}\text { P1-4 } \\
\text { P5 and } \\
\text { above }\end{array}$ & $47(45.63 \%)$ & $09(19.15 \%)$ & $11(23.40 \%)$ \\
\hline
\end{tabular}

TABLE IV:

DISTRIBUTION OF RISK FACTORS AMONG SCREENED PREGNANT WOMEN $(n=103)$

\begin{tabular}{|l|c|}
\hline \multicolumn{1}{|c|}{ Risk factor } & Number of women \\
\hline History of injections/infusions & $103(100 \%)$ \\
History of ear and/or nose prick & $103(100 \%)$ \\
History of blood transfusion & $21(20.39 \%)$ \\
History of jaundice & $13(12.62 \%)$ \\
History of jaundice in partner & $09(8.74 \%)$ \\
\hline
\end{tabular}

\section{DISCUSSION}

For this study, a small number of women underwent the screening test for viral hepatitis B or C carrier state and nearly one third of them turned out sero-positive, which is a significantly high proportion. Another important aspect of our findings is that the number of women positive for anti-HCV test was higher than those positive for HBsAg, though, most of the risk factors regarding transmission of both infections are same like needle pricks, repeated injections and blood transfusions. Similar findings have also been obtained 
in studies from Western Europe. ${ }^{6}$ Higher frequency in advanced age and parity may indicate an association of HCV transmission with past obstetrical /surgical procedures. ${ }^{7}$ However, relatively low figure for HBV marker is possibly a result of routine screening of blood donors, increased public awareness and vaccination against $\mathrm{HBV}$ infection. Similar lower figures (3.26\%) for HBV have also been reported by Aisha $\mathrm{M}$, et al. ${ }^{8}$ Prevalence of anti-HCV in pregnant women is reported as $0.1 \%$ to $2.4 \%$, which may be even higher in some endemic areas. ${ }^{9}$ All these carrier mothers are the reservoirs of virus transmission to their offspring which can further increase the number of infected / carrier individuals in the community. Antenatal HCV screening practices vary widely around the country, and therefore, many HCV-exposed infants are missed. The Royal Australian and New Zealand College of Obstetricians and Gynaecologists recommends universal antenatal screening for $\mathrm{HCV}^{10}$ Risk of perinatal transmission of infection exists in both types of infection and can occur both vertically as well as horizontally, surprisingly, most of the perinatal transmission of infection results from infant's exposure to infected maternal blood and genital tract secretions during delivery. Vertical transmission is low and linked to maternal viral load. ${ }^{11}$ Previous studies have shown that pregnancy does not influence the course of disease and neither liver disease increases the risk of obstetric complications. Hillemanns $P$, et al reported an increased risk of cesarean delivery among anti$\mathrm{HCV}$ positive mothers. ${ }^{12}$ Greatest transmission is noted in women with HCV RNA levels greater than 1 million copies/ml and co-infection with HIV increases the rate of transmission 4 to 5 fold. ${ }^{13}$ Mothers positive for only HBsAg carry only $10-20 \%$ risk of perinatal transmission of infection but if they are positive for $\mathrm{HbeAg}$, the risk increases up to $90 \%{ }^{14}$ Less number of women being infected with HBV may point to the success of vaccination programme but need to be evaluated further. Association of higher age and parity with HCV in this study points towards quality of past obstetrical care received by the women. These epidemiological characteristics need to be further evaluated to determine effective preventive measures. Major limitations of this study were small sample size, lack of uniform testing technique and lack of advanced statistical analysis of the data. However, despite these limitations, we conclude that frequency of HBV and HCV sero-positivity in pregnant women in our set up is alarmingly high. These sero-positive mothers are the reservoirs for deadly viruses and can transmit this virus to their offspring and their health care providers. Therefore, it is recommended that hepatitis B vaccination should be freely available to all newborns and primary prevention of hepatitis $C$ should be emphasized. The risk of spread of the infection can also be eliminated through strictly following instructions regarding body fluid management, and disposal of sharps and waste in the healthcare institutions. Antenatal screening for HBV and HCV for every woman is also recommended.

\section{REFERENCES}

1 Wright TL. Introduction to chronic hepatitis B infection. Am J Gastroenterol. 2006;101(Suppl 1):1-6.

2. Conte D, Fraquelli M, Prati D, et al. Prevalence and clinical course of chronic hepatitis $C$ virus $(\mathrm{HCV})$ infection and rate of $\mathrm{HCV}$ vertical transmission in a cohort of 15,250 pregnant women. Hepatology. 2000;31: 751-755.

3. Healy CM, Cafferkey MT, Conroy A, et al. Hepatitis $C$ infection in an Irish antenatal population. Ir J Med Sci. 2000;169(3):180-2.

4. Njouom R, Pasquier C, Ayouba A, et al. Hepatitis $C$ virus infection among pregnant women in Yaounde, Cameroon. Prevalence, viremia and genotypes. J Med Virol. 2003; 69(3): 384-90.

5. Nadir A, Siddiqui AR, Butt A. Hepatitis B: A deadly pathogen requiring urgent government attention. Inf Dis J Pak. 2002: 115-19.

6. Hillemanns $P$, Langenegger $P$, Langer $B C$, et al. Prevalence and follow up of hepatitis $C$ virus infection in pregnancy. Neonatol.1998; 202 (3):127-30.

7. Aisha M, Hashmi $H$, Syed S, et al. Hepatitis B markers in mother and its transmission in newborn. J Coll Physicians Surg Pak. 2002;12(4): 240-242.

8. Jaferry T, Tariq N, Ayub R, Yawar A. Frequency of hepatitis in pregnancy and pregnancy outcome. J Coll Physicians Surg Pak.2005;15(11):716-9.

9. Roberts EA, Yenug L. Maternal to infant transmission of hepatitis $C$ virus infection. Hepatology. 2002; 36: 106-13.

10. Spencer JD, Tibbits D, Tippet C, et al. Review of 
antenatal testing policies and practice for HIV and hepatitis C infection. Aust N Z J Public Health. 2003; 27:614-19.

11. Menendez C, Sanchez-Tapias JM, Kahigwa E, et al. Prevalence and mother to fetus transmission of hepatitis viruses B, C and E in Southern Tanzania. J Med Virol.1999;58(3):215-20.

12. Hillemanns $P$, Dannecker $C$, Kimmig $R$, Hasbargen $U$. Obstetric risk and vertical transmission of hepatitis $C$ virus infection in pregnancy. Acta Obstet Gynecol Scand. 2000;79

\section{(7):543-7.}

13. Fiore JR, Volpe A, Tosatti MA, et al. High seroprevalence of human herpes virus 8 in HIV-1 infected pregnant women of Southeastern Italy: association with injection drug use and hepatitis $C$ virus infection. J Med Virol. 2004;72 (4):656-60.

14. Shah NH and Shabbier G. Review of published literature on hepatitis $B$ and $C$ virus prevalence in Pakistan. J Coll Physicians Surg Pak. 2002;12 (6):368-371.

AUTHOR AFFILIATION:

Dr. Sajida Yousfani (Corresponding Author)

Assistant Professor

Department of Gynaecology and Obstetrics Liaquat University of Medical and Health Sciences (LUMHS) Jamshoro-Sindh.

Dr. Firdous Mumtaz

Associate Professor

Department of Gynaecology and Obstetrics

LUMHS Jamshoro.

Prof. Amna Memon

Department of Gynaecology and Obstetrics

LUMHS Jamshoro.

Dr. Muhammad Ali Memon

The Aga Khan University

Karachi - Sindh.

Dr. Raheel Sikandar

Assistant Professor

Department of Gynaecology and Obstetrics

LUMHS Jamshoro. 